\title{
HIDROLISIS PROTEIN TANDUK MUDA RUSA SAMBAR (Rusa unicolor) SERTA POTENSINYA SEBAGAI PENURUN RESIKO HIPERTENSI
}

\author{
Arif Ismanto \\ Jurusan Peternakan Fakultas Pertanian Universitas Mulawarman \\ Kampus Gunung Kelua Jl. Paser Belengkong P.O. BOX 1040 Telp. (0541) 749161, \\ 749314, Fax.738341 Samarinda 75123 \\ Corresponding email: arif_fpt01@yahoo.co.id
}

\begin{abstract}
ABSTRAK
Penelitian ini bertujuan untuk mengetahui tingkat hidrolisis tanduk muda rusa Sambar (Rusa unicolor) dengan enzim pencernaanm yaitu enzim pepsin dan tripsin, serta mengetahui adanya aktivitas Angiotensin I-Converting Enzyme Inhibitor dari protein tanduk muda tersebut. Protein tanduk muda rusa Sambar dihidrolisis dengan enzim pepsin dan tripsin selanjutnya diuji aktivitas penghambatan ACE (ACE-I). Hasil dari penelitian menunjukkan bahwa tanduk muda rusa Sambar mengandung air 11,34\%; protein sebesar 22,4\%; lemak $13,74 \%$ dan abu sebesar 37,29\%. Potensi sebagai agen antihipertensi dilakukan uji penghambatan angiotensin converting enzyme (ACE). Berdasarkan hasil penelitian diketahui adanya aktivitas penghambat ACE sebesar 83,38\% pada konsentrasi protein $1,266 \mathrm{mg} / \mathrm{ml}$.
\end{abstract}

Kata kunci: Tanduk muda rusa Sambar, Hidrolisis protein, Hipertensi, Angiotensin converting enzyme inhibitor.

\section{Pendahuluan}

Tekanan darah tinggi atau hipertensi, sebagai penyakit yang telah lama dikenal secara medis, adalah penyakit bersifat kronis yang umum diderita sebagian besar masyarakat saat ini. Hipertensi dapat diderita oleh kelompok sosial dan ekonomi manapun serta pria maupun wanita. Meningkatnya penderita hipertensi banyak disebabkan oleh gaya hidup yang kurang sehat. Studi epidemologi menunjukan bahwa arterosklerosis dan hipertensi paling umum menyebabkan patologi cerebrovascular, jantung, dan ginjal (Susalit et. al., 2001).

Baru-baru ini, ahli pangan sedang mengembangkan angiotensin converting enzym inhibitor (ACEI) yang berasal dari pangan alami (Murray dan Fitzgerard, 2007). Peptida ACEI berasal dari protein susu (kasein dan protein whey) dapat menunjukan pengaruh antihipertensi pada spontananeously hypertensive rats (SHR) (Yamamoto, et al., 1994; Nakamura, et. al., 1995). Penelitian peptida ACEI berasal dari produk unggas (daging ayam dan ovalbumin) menunjukan aktivitas potensial penghambat ACE (Fujita, et. al., 2000). Beberapa penelitian peptida ACEI berasal dari beberapa jenis ikan juga menunjukan aktivitas potensial penghambat ACE (Yokoyama, et. al., 1992; Matsui, et al., 1993).

Rusa sambar (Rusa unicolor) merupakan rusa terbesar untuk daerah tropik dengan sebaran di Indonesia terbatas di pulau Sumatera, Kalimantan dan pulau kecil di sekitar Sumatera (Semiadi, 2001). Rusa sambar memiliki potensi yang cukup baik untuk dikembangkan sebagai ternak terutama 
untuk pemanfaatan kebutuhan daging (venison). Selain daging, tanduk muda rusa Sambar merupakan bahan yang dapat dimanfaatkan oleh masyarakat. Namun demikian studi lebih lanjut tentang kemungkinan kandungan komponen aktif tanduk muda rusa Sambar belum pernah dilakukan. Penelitian yang lebih lanjut perlu dilakukan untuk mengangkat potensi indogenous spesies khususnya potensi tanduk muda rusa Sambar sebagai pangan yang mempunyai kemampuan sebagai pangan kesehatan.

\section{Metode}

\section{Preparasi Tanduk muda Rusa Sambar} Metode preparasi yang digunakan berdasarkan Jang \& Lee. (2005). Tanduk muda rusa Sambar disiapkan dan ditimbang sebanyak $100 \mathrm{~g}$, kemudian ditambahkan $200 \mathrm{ml}$ air dan dicampur dengan menggunakan blender kemudian dipanaskan selama 5 menit pada air mendidih. Sampel hasil preparasi tanduk rusa siap digunakan untuk pengujian selanjutnya.

\section{Hidrolisis Tanduk muda Rusa dengan Enzim Pepsin}

Hasil preparasi tanduk muda rusa Sambar diatur $\mathrm{pH}$-nya menjadi sekitar 2,0 dengan menambahkan $\mathrm{HCl} 1$ N. Enzim Pepsin sebanyak 0,01 g ditambahkan pada hasil preparasi tersebut dan diinkubasi pada suhu $37^{\circ} \mathrm{C}$ selama 2 jam. $\mathrm{pH}$ diatur menjadi $\mathrm{pH}$ netral dengan $1 \mathrm{M} \mathrm{NaOH}$, reaksi dihentikan dengan pemanasan pada suhu $95^{\circ} \mathrm{C}$ selama 10 menit, diikuti dengan pendinginan pada es. Hidrolisat rangah velvet rusa diambil sebanyak $10 \mathrm{~mL}$ dengan spuit yang dilengkapi dengan filter berukuran diameter $0,45 \mu \mathrm{m}$ untuk sampel eksperimen.

\section{Hidrolisis Tanduk muda Rusa dengan EnzimTripsin \\ Hidrolisat tanduk muda rusa} Sambar dari eksperimen sebelumnya ditambahkan tripsin sebanyak 0,01 g. Diinkubasikan selama 2 jam pada suhu $37^{\circ} \mathrm{C}$. Reaksi dihentikan dengan pemanasan pada suhu $95^{\circ} \mathrm{C}$ selama 10 menit, diikuti dengan pendinginan pada es. Selanjutnya diambil sebanyak $10 \mathrm{~mL}$ dengan spuit yang dilengkapi dengan filter berukuran diameter $0,45 \mu \mathrm{m}$ untuk sampel eksperimen.

\section{Analisis Proksimat}

Analisis komposisi kimia tanduk muda rusa yang dilakukan meliputi : analisis kadar air, kadar lemak, kadar protein dan kadar abu menurut metode analisis proksimat (AOAC, 1998).

\section{Pengujian aktivitas peptida ACE Inhibitor}

Sampel hidrolisat protein yang mengandung peptida inhibitor ACE dengan konsentrasi yang telah diketahui setelah hidrolisis pepsin dan tripsin dibuat dengan konsentrasi kelipatan setengah.sebanyak $6 \mu \mathrm{L}$ dicampur dengan $50 \mu \mathrm{L} 7,6 \mathrm{mM}$ substrat $\mathrm{HHL}$ yang dilarutkan dalam $100 \mathrm{mM}$ borate buffer (pH 8.3) dan $608 \mathrm{mMNaCl}$.

Sebelum direaksikan dengan ACE, dilakukan preinkubasi sampel selama 5 menit dalam waterbath pada suhu $37^{\circ} \mathrm{C}$. Reaksi dimulai dengan penambahan $20 \mu \mathrm{L} 60 \mathrm{mU} / \mathrm{mL}$ ACE yang dilarutkan dengan borate buffer $(\mathrm{pH}$ 8.3). Inkubasi dilakukan di dalam waterbath selama 30 menit pada suhu $37^{\circ} \mathrm{C}$. Reaksi dihentikan dengan penambahan $554 \mathrm{~L} 0.1 \mathrm{M} \mathrm{HCl}$, kecuali pada blanko yang telah ditambah $554 \mathrm{~L}$ $0.1 \mathrm{M} \mathrm{HCl}$ sebelum inkubasi. Produk dari reaksi (hippuric acid) diekstrasi dengan penambahan $1.5 \mathrm{~mL}$ ethyl acetate, dan digojok selama 2 menit. Campuran kemudian disentrifuse pada kecepatan $2500 \mathrm{rpm}(117 \times 10 \mathrm{~g})$ selama 15 menit. 
Satu milliliter supernatant diambil dan dipindahkan pada tabung reaksi yang lain, kemudian dikeringkan pada suhu $100{ }^{\circ} \mathrm{C}$ selama 10 menit. Tabung reaksi kemudian didinginkan pada suhu ruangan selama 10 menit, kemudian ditambahkan $1 \mathrm{~mL} 1 \mathrm{M} \mathrm{NaCl}$. Tabung divortex selama 30 detik. Asam hipuric yang dibebaskan oleh ACE ditentukan dengan spektrofotometer dengan panjang gelombang $228 \mathrm{~nm}$.

Aktivitas penghambatan ACE dapat dihitung dengan rumus :

$\begin{aligned} \text { Inhibition } & =(\mathrm{Ec}-\mathrm{Es}) /(\mathrm{Ec}-\mathrm{Eb}) \times 100 \% \\ \mathrm{Ec} & =\text { absorbansi kontrol } \\ \mathrm{Es} & =\text { absorbansi sampel } \\ \mathrm{Eb} & =\text { absorbansi blanko }\end{aligned}$

(Katayama, 2007)

\section{Hasil Penelitian}

\section{Komposisi Kimia Velvet}

Berdasarkan analisis komposisi kimia tanduk muda yang sudah dilakukan, diperoleh data sebagaimana tercantum pada Tabel 1.

Kadar protein kasar tanduk muda yang digunakan dalam penelitian ini adalah sebesar 54,43\%. Lima puluh empat persen protein tanduk muda tersebut terdiri atas kolagen, asam amino dan proteoglikan. Asam amino yang terkandung adalah sebanyak 14 jenis asam amino, yaitu : aspartat, glutamat, serin, histidin, glisin, threonin, arginin, alanin, tirosin, valin, phenilalanin, ileusin, leusin, dan lisin (Jamal, et al., 2005). Enam jenis asam amino yang tidak terdapat dalam tanduk muda yaitu prolin, tryptophan, sistein, asparagin, methionin, dan glutamin.

Tabel 1. Komposisi kimia ranggah velvet

\begin{tabular}{ccc}
\hline No. & Komposisi & Tanduk muda (\%) \\
\hline 1 & Kadar air & $11,34 \pm 0,12$ \\
2 & Protein kasar & $54,43 \pm 0.48$ \\
3 & Lemak kasar & $13,74 \pm 0,01$ \\
4 & Abu & $37,29 \pm 0,01$ \\
\hline
\end{tabular}

Sumber : Hasil analisis proksimat di Laboratorium Makanan Ternak Fakultas Peternakan UGM

Protein dari tanduk muda merupakan bahan dasar yang akan dievaluasi tingkat keberhasilan hidrolisisnya dan akan diselidiki potensinya sebagai sumber peptida. Peptida-peptida fungsional ditemukan dan diisolasi dari beberapa jenis bahan diantaranya : gelatin, kasein, dan protein ikan. Sebagian dari peptida tersebut mempunyai asam amino aromatik prolin, tirosin, atau triptophan pada $\mathrm{C}$ terminal (Saiga et al., 2006). Tanduk muda mengandung 2 buah asam amino aromatik yaitu triptophan dan tirosin, tetapi asam amino prolin tidak terkandung di dalamnya. Meskipun demikian, Cheung, et al. (1980) menyatakan bahwa kemampuan peptida ACE Inhibitor akan semakin kuat ketika terdapat dipeptida seperti -His-Leu, Phe-Arg, dan -Ala-Pro pada terminal C. Penelitian sebelumnya menunjukkan bahwa susunan peptida penghambat ACE beberapa bahan sumber peptida bioaktif diantaranya yaitu : Arg-Met-Leu-Gly-Gln-Thr-Pro, GlyGln, dan Thr-Lys berasal dari porcine troponin; Gly-Phe-His-Ile \& Asp-Phe- 
His-Ile-Asn- berasal dari daging sapi; Leu-Lys-Ala \& Phe-Gln-Lys-Pro-LysArg berasal dari ayam; dan Ile-Trp \& Leu-Trp berasal dari ikan salmon. Sehingga apabila ditinjau dari komposisi asam amino pada tanduk muda, tanduk muda masih mempunyai kemungkinan untuk membentuk susunan peptida penghambat ACE. Hasil analisis laboratorium pada penelitian sebelumnya juga mengungkapkan bahwa tanduk muda mengandung profil nutrisi yang sangat komprehensif meliputi kolagen, asamasam amino, asam-asam lemak esensial, mineral-mineral dan protein fungsional lainnya yang seluruhnya merupakan komponen-komponen vital bagi fungsi metabolisme manusia.

Kadar air, kadar lemak kasar dan kadar abu pada tanduk muda berturutturut adalah : $11,34 \pm 0,12 \%, 13,74 \pm$ $0,01 \%$ dan 37,29 $\pm 0,01 \%$. Kadar air dan kadar lemak pada tanduk muda relatif rendah jika dibandingkan dengan daging rusa, hal ini disebabkan proses penyiapan tanduk muda yang meliputi beberapa tahapan yaitu : pemotongan ranggah, pengirisan menjadi lempengan tipis, pengovenan dan penumbukan (penghalusan). Proses-proses penyiapan ranggah tersebut, terutama pada proses pengeringan dengan menggunakan oven, dimungkinkan akan mengurangi kadar air dan kadar lemak ranggah velvet. Pengeringan dengan oven pada pembuatan tanduk muda dilakukan selama 18 jam dengan suhu $\pm 55{ }^{0} \mathrm{C}$. Pengeringan harus dilakukan untuk mendapatkan produk ranggah dengan tekstur yang kering sehingga memudahkan untuk penghalusan serta menurunkan resiko kerusakan selama penyimpanan.

Enzim yang digunakan adalah pepsin dan tripsin. Pepsin adalah enzim yang terdapat dalam lambung yang akan mencerna protein dengan memecah protein menjadi bagian-bagian yang lebih kecil (Bunnel, 1999). Sedangkan tripsin, menurut Antoninil dan Ascenzi (1981), adalah enzim protease yang ditemukan dalam sistem pencernaan. Tripsin diproduksi di pankreas sebagai aktif proenzyme tripsinogen. Enzim ini memotong peptida rantai terutama pada karboksil sisi asam amino lisin atau arginin, kecuali jika baik diikuti oleh prolin. Pada penelitian mengenai digesti dengan enzim protease yang lain, yaitu bromelin, diketahui bahwa bromelin lebih aktif terhadap kolagen dari pada protein myofibril, bromelin tidak hanya mengubah kolagen menjadi gelatin, tetapi juga mendigesti molekul gelatin (Suhermiyati dan Setiyawati, 2001).

\section{Aktivitas Penghambat ACE}

Hidrolisat protein diperoleh melalui proses hidrolisis dengan enzim pepsin yang kemudian dilanjutkan dengan enzim tripsin menghasilkan peptida-peptida sederhana. Tabel 2 . menunjukkan aktivitas penghambatan ACE dari hidrolisat protein tanduk muda rusa Sambar.

Tabel 2. Persentase inhibisi (\%) dan konsentrasi sampel 1 sampai dengan sampel 5

\begin{tabular}{cccccc}
\hline & \multicolumn{5}{c}{ Ulangan } \\
\cline { 2 - 6 } & 1 & 2 & 3 & 4 & 5 \\
\hline Konsentrasi (mg/ml) & 1,266 & 0,633 & 0,320 & 0,158 & 0,079 \\
Aktivitas Inhibisi (\%) & 83,38 & 48,94 & 29,09 & 17,19 & 5,88 \\
\hline
\end{tabular}


Berdasarkan Tabel 2 hidrolisat protein tanduk muda rusa Sambar memiliki aktivitas penghambatan ACE, hal tersebut menunjukkan bahwa tanduk muda rusa Sambar memiliki kemampuan sebagai agen penurun resiko hipertensi. Kemampuan hidrolisat protein tanduk muda rusa Sambar dalam menghambat aktivitas ACE sebesar 83,38 \% pada konsentrasi protein $1,266 \mathrm{mg} / \mathrm{ml}$. Nilai aktivitas penghambatan terhadap ACE tersebut terbilang cukup tinggi dibandingkan penelitian terdahulu.

Nilai aktivitas penghambatan terhadap ACE dari hidrolisat protein tergantung dari beberapa faktor, antara lain bahan atau protein yang dihidrolisis dan enzim yang digunakan. Hasil uji penghambatan ACE asal peptida tulang ayam yang dilakukan Cheng et al. (2008), menunjukkan bahwa peptida tulang ayam yang telah dihidrolisis dengan enzim tripsin selama dua jam memiliki kemampuan menghambat ACE sebesar 56,80\%, sedangkan hasil penelitian terhadap hidrolisis kolagen ayam yang dihidrolisis dengan protease Aspergillus orizae $0,1 \%$ Saiga et al. (2008) menunjukkan aktivitas penghambatan sebesar 30\%.

Aktivitas penghambatan ACE oleh suatu zat dapat dipengaruhi oleh beberapa faktor. Menurut Saiga et al; (2008) bantuan enzimatik akan meningkatkan aktivitas penghambatan terhadap ACE. Bantuan enzimatik menyebabkan pemecahan protein menjadi peptida kecil (di-dan tripeptida) dan peptida besar (10 sampai 51 asam amino) sehingga dapat diserap utuh melalui usus dan menghasilkan efek biologis pada tingkat jaringan. Peptida makanan diserap memainkan peran dalam modulasi fungsi organ dan perkembangan penyakit (Roberts et. al., 1999). Faktor lain yang berperan dalam aktivitas penghambatan terhadap ACE dari suatu zat adalah aktivitas beberapa enzim pencernaan seperti pepsin, tripsin dan kemotripsin. Enzim-enzim tersebut melalui proses hidrolisis, dapat melepaskan ACEI dan atau peptida antihipertensi dari protein makanan (Hernández-Ledesma et al., 2011). Beberapa hal seperti pengolahan makanan, misalnya perlakuan panas dan tekanan hidrostatik tinggi, dan metode yang digunakan untuk memasak juga mempengaruhi aktivitas penghambatan suatu zat terhadap ACE dengan cara meningkatkan daya cerna protein dan pelepasan peptida. (Hernández-Ledesma et al., 2011).

\section{Kesimpulan}

Hidrolisat protein tanduk muda rusa Sambar dengan enzim pepsin yang kemudian dilanjutkan dengan enzim tripsin memiliki potensi sebagai penghambat ACE. Aktivitas penghambatan ACE dari tanduk muda rusa Sambar sebesar $83,38 \%$ pada konsentrasi protein sebesar 1,266 mg/ml.

\section{Daftar Pustaka}

1. AOAC.1998. Official Methods of Analysis of AOAC International. Association of Official Analysis Chemists International. doi:10.3109/15563657608988149

2. Bunnel, T. 1999. The Effect of "Healing with Intent" on Pepsin Enzyme Activity. J. Sci. Exp. 13( 2) : 139-148.

3. Cheng, F.-Y., Liu, Y.-T., Wan, T.-C., Lin, L.-C., \& Sakata, R. 2008. The development of angiotensin Iconverting enzyme inhibitor derived from chicken bone protein. Animal Science Journal, 79(1), 122-128. doi:10.1111/j.1740-0929.2007.00507

4. Cheung, H., F. Wang, \& M.A. Ondetti. 1980. Binding of Peptide Substrates and Inhibitors, 255(2), 401-405.

5. Fujita, H., K. Yokoyama, and M. Yoshikawa. 2000. Classification and antihypertensive activity of angiotensin I-converting enzyme inhibitory peptides derived from food 
proteins. Journal of Food Science. Vol. 65: 564-594.

6. Hernández-Ledesma, B., M. M Contreras, I. Recio. 2011. Antihypertensive peptides: production, bioavailability and incorporation into foods. Advances in Colloid and Interface Science. Vol. 165: 23-35

7. Jamal, Y., G. Semiadi dan R.T.P Nugraha. 2005. Kualitas produk ranggah muda rusa sambar tangkaran. Berkala Ilmiah Biologi (UGM) 4: 325-336.

8. Jang, A , \& M. Lee. 2005. Purification and identification of angiotensin converting enzyme inhibitory peptides from beef hydrolysates. Meat Science, 69(4), 653-61.

doi:10.1016/j.meatsci.2004.10.014

9. Katayama, T., K. Katayama, Jamhari, T, Mori, S. Kawahara, K. Miake, Y. Kodama, M. Sugiyama, Y. Kawamura, T. Takayama, M. Maruyama, M. Muguruma. 2007. Angiotensin I-converting enzym inhibitor peptide derived from procine skeletal muscle myosin and it's antihypertensive activity in spontaneously hypertensive rats. Journal of Food Science. Vol. 72: S702-S706.

10. Matsui, T., H. Matsufuji, E. Seki, K. Osajima, M. Nakashima, and Y. Osajima. 1993. Inhibition of angiotensin I-converting enzyme by bacillus licheniformis alkaline protease hydrolyzates derived from sardine muscle. Bioscience Biotechnology Biochemical. Vol. 57(6): 922-925.

11. Murray, B. A., and RR. J. Fitzgerard. 2007. Angiotensin Converting Enzyme Peptides Derived from Food Protein: Biochemistry, Bioactivity, And Production. Current Pharmaceutical Design. Vol. 13: 773-791.
12. Roberts, PR,. Burney JD, Black KW, Zaloga GP. 1999. Effect of chain length on absorption of biologically active peptides from the gastrointestinal tract digestion. International Journal of Gastroenterology. Vol. 60:332-337.

13. Saiga, A., Okumura, T., Makihara, T., Katsuda, S.-I., Morimatsu, F., \& Nishimura, T. 2006. Action mechanism of an angiotensin Iconverting enzyme inhibitory peptide derived from chicken breast muscle. Journal of Agricultural and Food Chemistry, 54, 942-945. doi:10.1021/jf0508201

14. Saiga, A., T. Okumura, T. Makihara, S. Katsuda, F. Morimatsu, and T. Nishimura, 2006. Action mechanism of an angiotensin I-converting enzyme inhibitory peptide derived from chicken breast muscle. J. Agr. Food Chem. 54: 942-945.

15. Semiadi. 2001. Potensi pengembangan peternakan rusa sambar di Kabupaten Paser. Samarinda.

16. Suhermiyati, S.. S. J. Setiyawati. 2008. Potensi limbah nanas untuk peningkatan kualitas limbah lkan tongkol sebagai bahan pakan unggas. J. Anim. Prod. 10, (3) : $174-178$.

17. Susalit,E., E.J Kapojos, dan H.R Lubis. 2001. Buku Ajar Ilmu Penyakit Dalam: Hipertensi Primer. Balai Penerbit FKUI. Jakarta

18. Yamamoto, N., A. Akino, T. Takano. 1994. Antihypertensive effect of the peptides derived from casein by an extracellular proteinase from Lactobacillus helveticus CP790. Journal of Dairy Science. Vol. 77: 917-922.

19. Yokoyama, K.; H. Chiba.; M. Yoshikawa. 1992. Peptide inhibitors for angiotensin I-converting enzyme from a thermolysin digest of dried bonito. Bioscience, Biotechnology, and Biochemistry. Vol. 56:15411545 . 